\title{
A longitudinal analysis of associations between traffic- related air pollution with asthma, allergies and sensitization in the GINIplus and LISAplus birth cohorts
}

Background: There is a need to study whether the adverse effects of traffic-related air pollution (TRAP) on childhood asthma and allergic diseases documented during early-life persist into later childhood. This longitudinal study examined whether TRAP is associated with the prevalence of asthma, allergic rhinitis and aeroallergen sensitization in two German cohorts followed from birth to 10 years.

Materials: Questionnaire-derived annual reports of doctor diagnosed asthma and allergic rhinitis, as well as eye and nose symptoms, were collected from 6,604 children. Aeroallergen sensitization was assessed for 3,655 children who provided blood samples. Associations between these health outcomes and nitrogen dioxide $\left(\mathrm{NO}_{2}\right.$ ), particles with aerodynamic diameters less than $2.5 \mu \mathrm{g} / \mathrm{m}^{3}$ $\left(\mathrm{PM}_{2.5}\right)$ mass, $\mathrm{PM}_{2.5}$ absorbance and ozone, individually estimated for each child at the birth, six and 10 year home addresses, were assessed using generalized estimation equations including adjustments for relevant covariates. Odds ratios [95\% confidence intervals] per increase in interquartile range of pollutant are presented for the total population and per geographical area (GINI/LISA South, GINI/LISA North and LISA East, Germany).

Results: The risk estimates for the total population were generally null across outcomes and pollutants. The area-specific results were heterogeneous. In GINI/LISA North, all associations were null. In LISA East, associations with ozone were elevated for all outcomes, and those for allergic rhinitis and eyes and nose symptom prevalence reached statistical significance $(1.30$ [1.02, 1.64] and $1.35[1.16,1.59]$, respectively). For GINI/LISA South, two associations with aeroallergen sensitization were significant $\left(0.84[0.73,0.97]\right.$ for $\mathrm{NO}_{2}$ and $0.87[0.78,0.97]$ for $\mathrm{PM}_{2.5}$ absorbance), as well as the association between allergic rhinitis and $\mathrm{PM}_{2.5}$ absorbance $(0.83[0.72$, 0.96]).

Conclusions: This study did not find consistent evidence that TRAP increases the prevalence of childhood asthma, allergic rhinitis or aeroallergen sensitization in later childhood using data from birth cohort participants followed for 10 years in three locations in Germany. Results were heterogeneous across the three areas investigated. 
1 Elaine Fuertes ${ }^{1,2}$, Marie Standl ${ }^{1,3}$, Josef Cyrys ${ }^{4,5}$, Dietrich Berdel ${ }^{6}$, Andrea von Berg ${ }^{7}$, Carl-Peter

2 Bauer $^{7}$, Ursula Krämer ${ }^{8}$, Dorothea Sugiri ${ }^{8}$, Irina Lehmann ${ }^{9}$, Sibylle Koletzko ${ }^{10}$, Chris Carlsten ${ }^{2,11}$, Michael Brauer ${ }^{2,11}$, Joachim Heinrich ${ }^{1}$
1. Institute of Epidemiology I, Helmholtz Zentrum München, German Research Center for
$\begin{array}{lll}5 & & \text { Environmental Health, Neuherberg, Germany } \\ 6 & 2 . & \text { School of Population and Public Health, Univ }\end{array}$
$\begin{array}{lll}6 & 2 . & \text { School } \\ 7 & & \text { Canada }\end{array}$
8 3. Institute for Medical Informatics, Biometry and Epidemiology, University of Munich,
$9 \quad$ Munich, Germany
4. Institute of Epidemiology II, Helmholtz Zentrum München, German Research Center for Environmental Health, Neuherberg, Germany
5. Environmental Science Center, University of Augsburg, Augsburg, Germany
6. Department of Pediatrics, Marien-Hospital, Wesel, Germany
7. Department of Pediatrics, Technical University of Munich, Munich, Germany
8. IUF - Leibniz Research Institute for Environmental Medicine, University of
Düsseldorf, Düsseldorf, Germany
9. UFZ Department of Environmental Immunology/Core Facility Studies, Helmholtz Centre for Environmental Research, Leipzig, Germany
10. Division of Paediatric Gastroenterology and Hepatology, Ludwig-Maximilians- University of Munich, Dr. von Hauner Children's Hospital, Munich, Germany
11. Department of Medicine, University of British Columbia, Vancouver, Canada

10

\section{Corresponding author}

Joachim Heinrich

24 Ingolstädter Landstr. 1, 85758 Neuherberg, Germany

25 +49-(0)89-3187-4150

26 heinrich@helmholtz-muenchen.de 
The rapid rise in asthma and allergic diseases in recent decades suggests a role for environmental factors. Whether traffic-related air pollution (TRAP) contributes to the development of childhood asthma, allergy and related symptoms has been the topic of several studies. Although a review in 2010 concluded that the evidence of an association between TRAP and asthma onset and prevalence remains insufficient to infer a causal relationship (Tager et al. 2010), support for this association continues to build, including from genetic and gene-environment studies (Carlsten and Melén 2012; Holloway et al. 2012). The evidence for other non-asthma allergic phenotypes, such as allergic rhinitis, eczema and aeroallergen sensitization, is generally weaker (Fuertes et al. 2013; Tager et al. 2010).

\section{Several epidemiological studies have examined the link between air pollution and allergic} diseases in children in early life (Clark et al. 2010; Morgenstern et al. 2007; Brauer et al. 2002; Gehring et al. 2002) and childhood (Carlsten et al. 2010; Morgenstern et al. 2008; Nordling et al. 2008; Brauer et al. 2007; McConnell et al. 2006). All of these aforementioned studies report positive associations with at least one respiratory or allergic health outcome, despite the challenges associated with accurately assessing air pollution exposure levels and allergic health status in young children. A study on older children (10-11 years) found no association between TRAP and general sensitization, although sensitization to house dust mites was associated with lifetime air pollution exposure (Oftedal et al. 2007). Two recent large cross-sectional multi-center European studies found no clear association between individually assigned TRAP exposures and asthma or wheeze at four to five and eight to 10 years in approximately 10,000 children (Molter A et al. submitted, unpublished data) and sensitization at four to six and eight to 10 years in approximately 7,000 children (Gruzieva et al. in press).

Only two longitudinal epidemiological analyses incorporating health data from birth up to eight years of age have been conducted. Gehring et al. (2010) reported positive associations between TRAP and the incidence and prevalence of asthma and the prevalence of asthma symptoms in a study of 3,863 Dutch children (Gehring et al. 2010). Positive associations were also found for allergic rhinitis, but only among non-movers. No associations were found for sensitization at eight years, despite a previous positive finding at four years in this same cohort (Brauer et al. 2007). Gruzieva et al (2012) also found no association between TRAP and allergic sensitization 
at eight years in a Swedish birth cohort (Gruzieva et al. 2012), again despite a previous documented association at four years of age (Nordling et al. 2008). These results may suggest that the timing of air pollution exposure is important. This hypothesis, as well as the long-term impact of air pollution on allergic disease prevalence in later childhood, is best explored in the context of longitudinal birth cohorts (Braback and Forsberg 2009).

Recently, the 10 year follow-ups of the "German Infant study on the influence of Nutrition Intervention plus environmental and genetic influences on allergy development" (GINIplus) and "influence of Life style factors on the development of the Immune System and Allergies in East and West Germany plus the influence of traffic emissions and genetics" (LISAplus) birth cohort studies were completed. These studies are unique in their long-term and frequent follow-up, large sample sizes, extensive health, demographic and lifestyle information, as well as the availability of air pollution estimates at different time points during life (birth, six and 10 years). Previously published results from these cohorts suggest a possible adverse role of TRAP on symptoms before the first two years of life (Morgenstern et al. 2007; Gehring et al. 2002) and several allergic outcomes at six years (Morgenstern et al. 2008) for children living in the Munich (GINI/LISA South) area. In the northern part of these cohorts (Wesel area, GINI/LISA North), associations were found only with the prevalence of eczema (Krämer et al. 2009). The current study builds on these past efforts by examining whether nitrogen dioxide $\left(\mathrm{NO}_{2}\right)$, particles with aerodynamic diameters less than $2.5 \mu \mathrm{g} / \mathrm{m}^{3}\left(\mathrm{PM}_{2.5}\right)$ mass, $\mathrm{PM}_{2.5}$ absorbance and ozone concentrations, the latter of which has not been previously considered in the context of the GINIplus and LISAplus studies, are associated with the prevalence of asthma, allergic rhinitis and aeroallergen sensitization among children followed for 10 years in three areas in Germany. 


\section{Study population}

GINIplus is a prospective birth cohort of 5,991 children born at full-term and normal weight recruited in the areas of GINI/LISA South (a predominantly urban area) and GINI/LISA North (a predominantly rural area) between 1995 and 1998. Children with at least one atopic parent or sibling were allocated to an intervention study arm which investigated the effect of different hydrolyzed formulas consumed during the first year of life on allergy development $(\mathrm{N}=2,252)$ (von Berg et al. 2003). All children whose parents did not give consent for the randomized clinical trial or who did not have a family history of allergic diseases were allocated to the observation study arm $(\mathrm{N}=3,739)$. LISAplus is a population-based prospective birth cohort of 3,095 children born at full-term and normal weight recruited in GINI/LISA South, GINI/LISA North, Leipzig (LISA East; formally part of Eastern Germany) and Bad Honnef between 19971999 (original study size 3,097 but two participants withdrew their consent to participate). Detailed descriptions of the recruitment and follow-up strategy for both cohorts are available (Filipiak et al. 2007; Heinrich et al. 2002). Both studies were approved by the local Ethics Committees (the Bavarian Board of Physicians (reference numbers: 01212 and 07098), University of Leipzig (reference number: 345/2007), and Board of Physicians of North-RhineWestphalia (reference numbers: 2003355 and 2008153)) and written consent was obtained from all parents of the participants.

\section{Questionnaire data}

Demographic and health data were collected using parent-completed questionnaires administered when the child was one, two, three, four, six and 10 years old for GINIplus participants and six, 12 and 18 months and two, four, six and 10 years old for LISAplus participants. Only information collected from three years onwards is included in this study as it is difficult to accurately diagnose allergic health outcomes at very young ages.

A doctor diagnosis of asthma was defined as a positive response to "In the last 6/12 months, has your child been diagnosed with asthma?" A doctor diagnosis of allergic rhinitis was defined as a positive response to "In the last 6/12 months, has your child been diagnosed with hayfever or allergic rhinitis?" For GINIplus, this information was collected in one question at the three, four and six year follow-ups (diagnosis of hayfever or allergic rhinitis, as aforementioned). For the 
data collected at the 10 year follow-up of GINIplus and for all LISAplus follow-ups, this information was collected in two separate questions which were subsequently combined. If the follow-up covered a period of greater than one year, the prevalence of the diagnosis was asked separately for each year. Ultimately, yearly diagnoses for both asthma and allergic rhinitis were available for age three to 10 years. Eyes and nose symptoms were assessed only at ages four, six and 10, and were defined based on two concomitant positive responses to "In the past 12 months, has your child had a clogged or itchy nose when he/she did not have a cold?" and "In the past 12 months, has your child had a clogged or itchy nose accompanied by watery eyes?", which is consistent with the rhinoconjunctivitis definition used in the International Study of Asthma and Allergies in Childhood (Aït-Khaled et al. 2009).

Specific immunoglobulin E against common aeroallergens was assessed at ages six and 10 years using the standardized CAP-RAST FEIA method (ThermoFischer, Freiburg, Germany). Sensitization to inhalant allergens (SX1: Dermatoph. Pteroyssinus (house dust mites), cats, dogs, cladosporium (mold), birch, rye, mugwort and timothy grass) were measured by a screening test, followed by single specific allergen tests if the overall screening test was positive. The detection limit of the CAP-RAST FEIA method is $0.35 \mathrm{kU} / \mathrm{L}$ IgE; a test was defined as positive if the specific immunoglobulin E value was greater or equal to this limit. Aeroallergens were classified as either outdoor (birch, rye, mugwort and timothy grass) or indoor (house dust mites, cats, dogs, and molds).

\section{Air pollution exposure}

As part of the ESCAPE collaboration (www.escapeproject.eu), ambient concentrations of $\mathrm{NO}_{2}$, $\mathrm{PM}_{2.5}$ mass and $\mathrm{PM}_{2.5}$ absorbance were estimated for each child's home address at birth, six and 10 years using land-use regression (LUR) models for children living in GINI/LISA South and GINI/LISA North (Beelen et al. 2013; Cyrys et al. 2012; Eeftens et al. 2012a; Eeftens et al. 2012b). For children living in LISA East, $\mathrm{NO}_{2}$ and $\mathrm{PM}_{2.5}$ mass estimates at the home address at birth and six years were derived from a similar LUR model developed as part of the earlier TRAPCA (Traffic Related Air Pollution and Childhood Asthma) collaboration which was conducted in the city of Munich, Germany (Cyrys et al. 2003; Brauer et al. 2003; Hoek et al. 2002). $\mathrm{PM}_{2.5}$ absorbance data are not available for LISA East. Ozone estimates from the "Air Pollution Modeling for Support to Policy on Health and Environmental Risk in Europe” (APMoSPHERE ) project (www.apmosphere.org) were also available. For this latter pollutant, a 
1x $1 \mathrm{~km}$ resolution concentration map was developed across 15 European Union States using several European-wide datasets on monitored air pollution, land cover, altitude, transport networks, meteorology and population, as previously described (Beelen et al. 2009). Data from this map were used to assign ozone concentrations to the birth and six year home addresses of all participants. Table 1 summaries the key characteristics of the models used to estimate individuallevel air pollution concentrations in the current study. As no air pollution models were developed for the Bad Honnef area, children from this city were excluded from all analyses $(\mathrm{N}=306)$.

\section{Statistical analysis}

All analyses were conducted using the statistical program R, version 2.13.1 (R Core Team 2012). Differences in population characteristics were assessed using the Chi-square test. Longitudinal associations between air pollutants estimated at the birth addresses with the prevalence of doctor diagnosed asthma and allergic rhinitis, nose and eye symptoms and aeroallergen sensitization were analyzed using generalized estimation equations with a logit link (geeglm function from the geepack package (Halekoh, Højsgaard, and Yan 2006)). An exchangeable correlation structure was used to account for repeated observations on the same individual.

All models were adjusted for sex, age, presence of older siblings (yes/no), parental history of atopy, parental education (originally defined using three categories based on the highest number of years of education of either parent, but collapsed into two categories due to low numbers in the lowest category: less than or equal to 10 years versus more than 10 years), maternal smoking during pregnancy, smoke exposure in the home (ever between birth and four years), contact with furry pets during the first year of life, use of gas stove for cooking during the first year of life, dampness or indoor molds in the home during the first year of life, intervention participation (GINIplus participants only), cohort and geographical area (for total models only). These confounders are the same as in previous analyses of these cohorts (Krämer et al. 2009; Morgenstern et al. 2008). Models for LISA East were not adjusted for intervention or cohort as only children for the LISAplus cohort were recruited from this area. Data on pneumonia infections in the first two years of life, which has been associated with air pollutants in a multicentre study (MacIntyre et al. in press), and percent of total green space and population density in a 500m buffer around the home address (GINI/LISA South and North only) were also available for sensitivity analyses. Elevated risks of disease were analyzed per interquartile range increase of each air pollutant. Odds ratios (OR) [95\% confidence intervals (95 CI)] are presented for the 
total population and by geographical area.

172 As $59 \%$ of the study population reported moving at least once during the first 10 years of life, 173 several sensitivity analyses were conducted to assess potential exposure misclassification. First, 174 all models were rerun using air pollutants estimated at the six and 10 year home addresses rather 175 than the birth address. Second, associations were assessed using the average of the birth, six and 17610 year air pollution concentrations for $\mathrm{NO}_{2}, \mathrm{PM}_{2.5}$ mass and $\mathrm{PM}_{2.5}$ absorbance, and the average of 177 the birth and six year concentrations for ozone (information at 10 years is not available). These 178 averages should better reflect a true life-time exposure for participants who moved between birth 179 and 10 years. Lastly, associations were examined separately for children who had and had not 180 moved during follow-up.

181 To address the potential importance of exposure timing, mutually adjusted models including both 182 birth and six or 10 year address pollution concentrations were examined when the pollutants were 183 not highly correlated (Pearson correlation coefficient $<0.70$ ). Each such correlation (for example, 184 between $\mathrm{NO}_{2}$ assessed at the birth address and $\mathrm{NO}_{2}$ assessed at the six year address) was 185 examined separately in the total and area-specific datasets. 
In total, 6,604 children had available information on at least one health outcome and air pollutant, 3655 of which also had available sensitization data at one time point (flow chart of study population provided in Supplemental Fig S1). Population characteristics and the prevalence of health outcomes at the age of 10 years are provided for the total population and by study area (Table 2), and for the subset of children who provided blood samples that were assessed for aeroallergen sensitization (Supplemental Table S1).

Compared to the original cohorts, children included in this study and the subset who provided blood samples were less likely to have been exposed to furry pets early in life or to have moved at least once between birth and 10 years, but more likely to have participated in the nutritional intervention (GINIplus participants only) and to have a parent with more than 10 years of education and a history of atopy. Furthermore, the children included in the main analyses were less likely to have been exposed to smoke in utero. The subset of children who provided blood samples were less likely to have been exposed to tobacco smoke in utero and during early life (14 years) or later childhood (6-10 years).

\section{Distribution of outcomes}

The period prevalences of doctor diagnosed asthma and allergic rhinitis are presented in Fig. 1. In the total population, the annual prevalence of doctor diagnosed asthma and allergic rhinitis ranged from $1.1 \%$ to $3.5 \%$ and from $1.6 \%$ to $10.0 \%$, respectively. The distribution of doctor diagnosed asthma and allergic rhinitis prevalence across areas was similar. Only at age nine and 10 years were the rates of doctor diagnosed allergic rhinitis significantly different across areas. The pooled prevalence of reported eye and nose symptoms rose steadily with age and differed by area $(3.7 \%, 6.8 \%$ and $13.3 \%$ for ages four, six and 10 years, respectively), as did the prevalence of aeroallergen sensitization (29.0\% and $40.2 \%$ for ages six and 10 years, respectively). The prevalence of eye and nose symptoms and aeroallergen sensitization was highest in GINI/LISA South and lowest in GINI/LISA North at almost all ages.

\section{Air pollution exposures}

213 The distributions of annual average air pollution estimates are presented in Table 3 for the total 
214 study population and by area. At the birth addresses, mean $\mathrm{NO}_{2}$ concentrations were highest in

215 GINI/LISA North $\left(23.8 \mu \mathrm{g} / \mathrm{m}^{3}\right)$, mean $\mathrm{PM}_{2.5}$ mass concentrations were highest in LISA East (17.5

$216 \mu \mathrm{g} / \mathrm{m}^{3}$ ) and mean $\mathrm{PM}_{2.5}$ absorbance and ozone concentrations were highest in GINI/LISA South

$217\left(1.710^{-5} / \mathrm{m}\right.$ and $45.8 \mu \mathrm{g} / \mathrm{m}^{3}$, respectively). As the GINI/LISA North area is affected by the

218 neighboring industrial Ruhr area in Germany, the elevated levels of $\mathrm{PM}_{2.5}$ mass but not $\mathrm{PM}_{2.5}$

219 absorbance in this area may suggest that there are $\mathrm{PM}_{2.5}$ mass sources other than traffic. The

220 correlations between $\mathrm{NO}_{2}$ and the other pollutants were moderate in the pooled data $(0.30,0.32$

221 and -0.50 for $\mathrm{PM}_{2.5}$ mass, $\mathrm{PM}_{2.5}$ absorbance and ozone, respectively).

222

223

224

225

226

227

228

229

230

231

232

233

234

235

236

237

238

239

240

241

242

243

\section{Total and area-specific associations}

Crude and adjusted associations between air pollution concentrations at the birth address and the prevalence of health outcomes were similar (adjusted associations provided in Table 4). The areaspecific results were heterogeneous. In GINI/LISA North, the estimates for allergic rhinitis and eye and nose symptom prevalence were elevated for $\mathrm{PM}_{2.5}$ mass $(1.22[0.99,1.50]$ and 1.19 [0.99, 1.43], respectively). In LISA East, the estimates for ozone were elevated for all four outcomes, and that for allergic rhinitis and nose and eye symptom prevalence reached statistical significance $(1.30$ [1.02, 1.64] and 1.35 [1.16, 1.59], respectively). For GINI/LISA South, two associations with aeroallergen sensitization were significant $\left(0.84[0.73,0.97]\right.$ for $\mathrm{NO}_{2}$ and $0.87[0.78,0.97]$ for $\mathrm{PM}_{2.5}$ absorbance), as well as the association between allergic rhinitis and $\mathrm{PM}_{2.5}$ absorbance $(0.83[0.72,0.96])$. Given the heterogeneous area-specific effects, and the large influence of the GINI/LISA South cohort which represents $50.9 \%$ of the study population, risk estimates for the total population were generally null.

\section{Sensitivity analyses}

Associations with sensitization did not differ when aeroallergens were stratified into indoor and outdoor categories. Analyses which considered atopic asthma and more general allergic rhinitis (doctor diagnosis or nose and eye symptoms) as alternate outcomes yielded similar associations. The results remained robust when the models were further adjusted for the percent total green space and population density in a 500m buffer around the home address (not done for LISA East) and upon adjustment for pneumonia infections in the first two years of life. Additional analyses stratified by sex, parental history of atopic disease or smoke exposure in the home during earlylife did not reveal a vulnerable subgroup. 
244 Air pollution concentrations estimated to the birth, six and 10 year addresses were generally

245 highly correlated with one another. Consequently, the risk estimates obtained using air pollution

246 concentrations estimated at the six and 10 year home addresses, and using the average of the

247 birth, six and 10 year air pollution estimates, were similar to those reported for air pollutants

248 estimated at the birth address (Supplemental Fig. S2 to Supplemental Fig. S4). When the pooled

249 analyses were run stratified by moving status (never moved versus moved at least once), the risk

250 estimates did not differ substantially between groups.

251 As air pollution concentrations were also generally highly correlated across time, we could only 252 examine the potential relative importance of varying time periods of exposure, using models 253 including both birth and six or 10 year address pollution concentrations, for a few time-point 254 combinations. The Pearson correlation coefficient was $<0.70$ for two time-point combinations in 255 the total data (between $\mathrm{NO}_{2}$ assessed at the birth and six year addresses as well as between $\mathrm{NO}_{2}$ 256 assessed at the birth and 10 year addresses), and seven, three and three time-point combinations 257 in the GINI/LISA South, GINI/LISA North and LISA East area-specific datasets. It was not 258 possible to decipher a consistent trend as to which time period may be most important from the 259 results of these models. 
261 In a longitudinal analysis of two German birth cohorts followed for 10 years, we did not find consistent evidence that TRAP exposure increases the risk of asthma, allergic rhinitis or aeroallergen sensitization in later childhood. The risk estimates for children living in two of the areas investigated (GINI/LISA North and LISA East) were null or elevated and those for the third (GINI/LISA South) tended to be below one. Given the heterogeneous area-specific effects, the risk estimates for the total population were inconclusive.

The factors driving the differing associations observed across areas are unknown. The sources of pollutants which likely differ by area may be one explanation; air pollution in all three areas is predominantly attributable to traffic-sources but industry also contributes to air pollution levels in GINI/LISA North (Beelen et al. 2013; Eeftens et al 2012). It is also possible that residual confounding may be influencing the results. We attempted to adjust for individual-level socioeconomic status using parental education as a proxy in the final models, and marital status at the time of birth and household income per person (calculated according to Sausenthaler et al. 2011) in sensitivity analyses, but these indicators may be imperfect markers of socio-economic factors. Socio-economic data at the neighborhood level is not available for a large proportion of participants, but has been shown not to strongly influence associations between air pollution and allergic outcomes in recent cross-sectional multi-center European studies (Molter A et al. submitted, unpublished data, and Gruzieva et al. in press). Effect estimates also remained robust upon adjustment for surrounding green space and population density.

The overall null findings reported here for the total population are in line with those of two large recent multi-center European studies on asthma (Molter A submitted, unpublished data) and sensitization (Gruzieva et al. in press), in which GINI/LISA South and GINI/LISA North were included. The current work differs from these previous studies in several respects. The current study uses a longitudinal analytical approach to optimize the use of the long-term prospectively collected health outcome data from three to 10 years, whereas the previous two studies examined cross-sectional associations at two time points. Furthermore, the two multi-center studies did not include the LISA East area, nor were allergic rhinitis or nose and eye symptoms considered as outcomes or ozone as an air pollutant. With respect to studies with a long-term longitudinal design, our findings for the total study population are in contrast to the positive associations 
observed between TRAP and asthma, as well as allergic rhinitis among non-movers, in a Dutch birth cohort followed for eight years (Gehring et al. 2010), but in line with the null associations for sensitization found in this Dutch cohort and in a similar Swedish birth cohort followed for eight years (Gruzieva et al. 2012).

The area-specific findings reported for the GINI/LISA North area are generally in line with a previous study in this area which examined associations with outcomes up to six years of age (Krämer et al. 2009). For GINI/LISA South, the current findings are more challenging to reconcile with those reported for outcomes up to six years of age (Morgenstern et al. 2008). The sample sizes differ slightly between this previous and the current analyses (3577 and 3941 children included, respectively), the definitions were not identical for all outcomes and there were some differences in the methodologies of the exposure assessment. In the previous work, exposure estimates were derived using a LUR model developed as part of the TRAPCA project (Brauer et al. 2003). This initial model was subsequently applied to the GINI/LISA South metropolitan area (TRAPCA II), which includes the city of Munich and the surrounding districts (Morgenstern et al. 2007). Exposure estimates derived from this TRAPCA II model were significantly positively associated with several health outcomes at six years among GINIplus and LISAplus participants living in GINI/LISA South (Morgenstern et al. 2008). In contrast, the current analysis for this area, which yielded null or negative associations, is based on estimates derived from a different LUR model developed almost a decade later as part of the ESCAPE collaboration. The ESCAPE models explain more variation than the TRAPCA II models and the root-mean standard errors of the ESCAPE models are lower than for TRAPCA II. The distribution of $\mathrm{PM}_{2.5}$ mass and absorbance concentrations are similar between the two datasets, however the $\mathrm{NO}_{2}$ estimates are lower in the more recently derived ESCAPE dataset. The lower estimated $\mathrm{NO}_{2}$ concentrations may reflect true decreases as the air pollution measurements for the ESCAPE models were taken a decade after those for the TRAPCA models and actual air pollution levels have decreased in GINI/LISA South during this time.

To date, very few studies have reported on associations with ozone. In the current study, results were generally non-significant, with only two positive associations found for LISA East. A few factors may have hindered our ability to detect consistent associations. First, the resolution of the database $(1 \mathrm{x} 1 \mathrm{~km})$ used to estimate ozone concentrations to the home address was lower than for the other pollutants. Second, as the spatial distribution of ozone is more even than for other 
pollutants, with the exception of areas very close to traffic, detecting true associations may be more difficult. Third, ozone concentrations are likely higher in rural areas compared to areas with greater traffic densities. However, effect estimates remained similar when the analyses were stratified into the inner city of Munich and surrounding areas (for GINI/LISA South) or when those not living in the city area were excluded (for GINI/LISA North).

Although the present work is among the very few studies which can utilize such a rich and large longitudinal dataset, certain limitations should be acknowledged. Participation bias is always a concern for cohorts with a long follow-up. Children included in this study differed from those in the initial birth cohort with regard to several characteristics and this non-random retention of participants may have affected the effect estimates. Of the 9086 children who were recruited in the GINIplus and LISAplus cohorts at birth, 5078 participated in the 10 year follow-up (55.9\%).Outcome misclassification is also a concern when analyzing data collected by questionnaires, but objective measures of aeroallergen sensitization were available for $55.3 \%$ (3655/6604) of the study population. No systematic differences between the results for the three parent-reported outcomes and the objective aeroallergen sensitization outcome are apparent. Furthermore, a positive response for asthma and allergic rhinitis was based on a parental-report of a doctor diagnosis and not only on a report of symptoms. The responses at the older ages are also likely more accurate as allergic disorders are easier to diagnose in later childhood. Finally, the data used to inform the LUR regression models for GINI/LISA South and North were collected approximately a decade after the commencement of the birth cohorts ( five years for LISA East) under the implicit assumption that the spatial variability in air pollution estimates would not have changed since the baseline periods of the cohorts. Three studies provide evidence supporting this assumption for $\mathrm{NO}_{2}$ over a period of seven to twelve years (Wang et al. 2013; Cesaroni et al. 2012; Eeftens et al. 2011).

A greater importance of early-life exposures has been hypothesized as a possible explanation for why positive associations with TRAP and sensitization have been found at four years of age but not at eight years in a Swedish birth cohort (Gruzieva et al. 2012), a finding that was also observed in a Dutch birth cohort (Gehring et al. 2010). One previous study has considered the relative importance of TRAP exposure timing and reported that $\mathrm{NO}$ and $\mathrm{PM}_{10}$ in utero exposures have an independent effect from post-birth exposures, although it was not possible for the authors to conclude which period may be most important (Clark et al. 2010). Similarly, the high 
352 correlation between exposures at birth and those at six and 10 years in the current study rendered 353 it challenging to disentangle the effects of these distinct exposure periods.

354 Although we conducted several sensitivity analyses to reduce potential moving-related exposure 355 misclassification and noted no changes in the results, it is possible that some exposure 356 misclassification remains, especially at the older ages when children spend a larger proportion of 357 their time at school. However, a Swedish and French study showed that exposures from traffic 358 assessed at the home address are good approximations of those at schools, possibly because 359 schools tend to be located in the close vicinity of homes (Gruzieva et al. 2012; Reungoat et al. 360 2005). Additionally, a study conducted in the United States found little differences between time361 weighted averages of diesel exposures estimated at all addresses where a child spent more than 362 eight hours per week and those estimated only at the home address (Ryan et al. 2008). 


\section{Conclusions}

364 We did not find consistent evidence that TRAP increases the risk of childhood asthma or allergic

365 diseases in later childhood using data from German birth cohort participants followed for 10

366 years. Heterogeneous results were noted across the three geographical areas investigated. 


\section{Acknowledgments}

367 GINIplus study group

368 Helmholtz Zentrum München, German Research Center for Environmental Health, Institute of

369 Epidemiology, GINI/LISA South (Heinrich J, Wichmann HE, Sausenthaler S, Zutavern A, Chen

370 CM, Schnappinger M, Rzehak P); Department of Pediatrics, Marien-Hospital, GINI/LISA North

371 (Berdel D, von Berg A, Beckmann C, Groß I); Department of Pediatrics, Ludwig-Maximilians-

372 University, GINI/LISA South (Koletzko S, Reinhardt D, Krauss-Etschmann S); Department of

373 Pediatrics, Technical University, GINI/LISA South (Bauer CP, Brockow I, Grübl A, Hoffmann

374 U); IUF-Institut für Umweltmedizinische Forschung at the Heinrich-Heine-University,

375 Düsseldorf (Krämer U, Link E, Klümper C); Centre for Allergy and Environment, Technical 376 University, GINI/LISA South (Behrendt H).

\section{LISAplus study group}

Helmholtz Zentrum München, German Research Center for Environmental Health, Institute of Epidemiology, GINI/LISA South (Heinrich J, Wichmann HE, Sausenthaler S, Chen CM, Schnappinger M); Department of Pediatrics, Municipal Hospital 'St.Georg', LISA East (Borte M, Diez U), Marien-Hospital GINI/LISA North, Department of Pediatrics, GINI/LISA North (von Berg A, Beckmann C, Groß I); Pediatric Practice, Bad Honnef (Schaaf B); Helmholtz Centre for Environmental Research-UFZ, Department of Environmental Immunology/Core Facility Studies, LISA East (Lehmann I, Bauer M, Gräbsch C, Röder S, Schilde M); University of LISA East, Institute of Hygiene and Environmental Medicine, LISA East (Herbarth O, Dick C, Magnus J); IUF-Institut für Umweltmedizinische Forschung, Düsseldorf (Krämer U, Link E, Klümper C); Technical University GINI/LISA South, Department of Pediatrics, GINI/LISA South (Bauer CP, Hoffmann U); ZAUM-Center for Allergy and Environment, Technical University, GINI/LISA South (Behrendt H, Grosch J, Martin F). 
Aït-Khaled N, Pearce N, Anderson H, Ellwood P, Montefort S, Shah J, ISAAC Phase Three Study Group. 2009. Global map of the prevalence of symptoms of rhinoconjunctivitis in children: The International Study of Asthma and Allergies in Childhood (ISAAC) Phase Three. Allergy 64:123-148.

Beelen R, Hoek G, Pebesma E, Vienneau D, de Hoogh K, Briggs DJ. 2009. Mapping of background air pollution at a fine spatial scale across the European Union. Science of The Total Environment 407(6):1852-1867. doi:10.1016/j.scitotenv.2008.11.048.

Beelen R, Hoek G, Vienneau D, Eeftens M, Dimakopoulou K, Pedeli X, Tsai M-Y, Künzli N, Schikowski T, Marcon A, Eriksen KT, Raaschou-Nielsen O, Stephanou E, Patelarou E, Lanki T, Yli-Tuomi T, Declercq C, Falq G, Stempfelet M, Birk M, Cyrys J, von Klot S, Nádor G, Varró MJ, Dėdelė A, Gražulevičienė R, Mölter A, Lindley S, Madsen C, Cesaroni G, Ranzi A, Badaloni C, Hoffmann B, Nonnemacher M, Krämer U, Kuhlbusch T, Cirach M, de Nazelle A, Nieuwenhuijsen M, Bellander T, Korek M, Olsson D, Strömgren M, Dons E, Jerrett M, Fischer P, Wang M, Brunekreef B, de Hoogh K. 2013. Development of NO2 and NOx land use regression models for estimating air pollution exposure in 36 study areas in Europe - the ESCAPE project. Atmospheric Environment 72:10-23. doi:10.1016/j.atmosenv.2013.02.037.

Braback L, Forsberg B. 2009. Does traffic exhaust contribute to the development of asthma and allergic sensitization in children: findings from recent cohort studies. Environmental Health 8(17):DOI:10.1186/1476-069X-8-17.

Brauer M, Hoek G, Vliet PV, Meliefste K, Fischer PH, Wijga A, Koopman LP, Neijens HJ, Gerritsen J, Kerkhof M, Heinrich J, Bellander T, Brunekreef B. 2002. Air pollution from traffic and the development of respiratory infections and asthmatic and allergic symptoms in children. American Journal of Respiratory and Critical Care Medicine 166(8):10921098. doi:10.1164/rccm.200108-007OC.

Brauer M, Hoek G, Smit HA, de Jongste JC, Gerritsen J, Postma DS, Kerkhof M, Brunekreef B. 2007. Air pollution and development of asthma, allergy and infections in a birth cohort. European Respiratory Journal 29(5):879 -888.

Brauer M, Hoek G, Vliet PV, Meliefste K, Fischer P, Gehring U, Heinrich J, Cyrys J, Bellander T, Lewne M, Brunekreef B. 2003. Estimating long-term average particulate air pollution concentrations: application of traffic indicators and geographic information systems. 
Epidemiology 14(2):228-239.

Carlsten C, Dybuncio A, Allen R, Becker AB, Chan-Yeung M, Brauer M. 2010. Traffic-related air pollution and incident asthma in a high-risk birth cohort: interaction with key candidate genes. Proceedings of the American Thoraic Society 7(2):153.

Carlsten C, Melén E. 2012. Air pollution, genetics, and allergy. Current Opinion in Allergy and Clinical Immunology 12(5):455-461. doi:10.1097/ACI.0b013e328357cc55.

Cesaroni G, Porta D, Badaloni C, Stafoggia M, Eeftens M, Meliefste K Forastiere F. 2012. Nitrogen dioxide levels estimated from land use regression models several years apart and association with mortality in a large cohort study. Environmental Health 11:48.

Clark NA, Demers PA, Karr CJ, Koehoorn M, Lencar C, Tamburic L, Brauer M. 2010. Effect of early life exposure to air pollution on development of childhood asthma. Environmental Health Perspectives 118(2):284-290..

Cyrys J, Eeftens M, Heinrich J, Ampe C, Armengaud A, Beelen R, Bellander T, Beregszaszi, T, Birk M, Cesaroni G, Cirach M, de Hoogh K, Nazelle AD, de Vocht F, Declercq C, Dėdelè A, Dimakopoulou K, Eriksen K, Galassi C, Gražulevičienė R, Grivas G, Gruzieva O, Gustafsson AH, Hoffmann B, Iakovides M, Ineichen A, Krämer U, Lanki T, Lozano P, Madsen C, Meliefste K, Modig L, Mölter A, Mosler G, Nieuwenhuijsen M, Nonnemacher M, Oldenwening M, Peters A, Pontet S, Probst-Hensch N, Quass U, Raaschou-Nielsen O, Ranzi A, Sugiri D, Stephanou EG, Taimisto P, Tsai M-Y, Vaskövi É, Villani S, Wang M, Brunekreef B, Hoek G. 2012. Variation of NO2 and NOx concentrations between and within 36 European study areas: results from the ESCAPE study. Atmospheric Environment 62:374-390.

Cyrys J, Heinrich J, Hoek G, Meliefste K, Lewné M, Gehring U, Bellander T, Fischer P, Vliet PV, Brauer M, Wichmann HE, Brunekreef B. 2003. Comparison between different trafficrelated particle indicators: elemental carbon (EC), PM2.5 mass, and absorbance. Journal of Exposure Science and Environmental Epidemiology 13(2):134-143.

391 Eeftens M, Beelen R, Fischer P, Brunekreef B, Meliefste K, Hoek G. Stability of measured and modelled spatial contrasts in NO2 over time. 2011. Occupational and Environmental Medicine 68(10);765-770.

Eeftens M, Beelen R, de Hoogh K, Bellander T, Cesaroni G, Cirach M, Declercq C Dédelè A, Dons E, de Nazelle A, Dimakopoulou K, Eriksen K, Falq G, Fisher P, Galassi C, Grazǔlevicǐene R, Heinrich J, Hoffmann B, Jerrett M, Keidel D, Korek M, Lanki T, 
Lindley S, Madsen C, Mölter A, Nádor G, Nieuwenhuijsen M, Nonnemacher M, Pedeli X, Raaschou-Nielsen O, Patelarou E, Quass U, Ranzi A, Schindler C, Stempfelet M, Stephanou E, Sugiri D, Tsai M-Y, Yli-Tuomi T, Varró, MJ, Vienneau D, von Klot S, Wolf K, Brunekfreef B, Hoek G. 2012. Development of land use regression models for PM2.5, PM2.5 absorbance, PM10 and PM coarse in 20 European study areas; results of the ESCAPE project. Environmental Science \& Technology 46(20):11195-11205. Eeftens, Marloes, Tsai M-Y, Ampe C, Anwander B, Beelen R, Bellander T, Cesaroni G, Cirach M, Cyrys J, de Hoogh K, de Nazelle A, de Vocht F, Declercq C, Dėdelè A, Eriksen K, Galassi C, Grazǔlevicǐene R, Grivas G, Heinrich J, Hoffmann B, Iakovides M, Ineichen A, Katsouyanni K, Korek M, Krämer U, Kuhlbusch T, Lanki T, Madsen C, Meliefste K, Mölter A, Mosler G, Nieuwenhuijsen M, Oldenwening M, Pennanen A, Probst-Hensch N, Quass U, Raaschou-Nielsen O, Ranzi A, Stephanou E, Sugiri D, Udvardy O, Vaskövi É, Weinmayr G, Brunekreef B, Hoek G. 2012. Spatial variation of PM2.5, PM10, PM2.5 absorbance and PM coarse concentrations between and within 20 European study areas and the relationship with NO2 - results of the ESCAPE project. Atmospheric Environment 62:303-317

Filipiak B, Zutavern A, Koletzko S, von Berg A, Brockow I, Grübl A, Berdel D, Reinhardt D, Bauer CP, Wichmann HE, Heinrich J. 2007. Solid food introduction in relation to eczema: results from a four-year prospective birth cohort study. The Journal of Pediatrics 151(4):352-358.

Fuertes E, Brauer M, MacIntyre E, Bauer M, Bellander T, von Berg A, Berdel D, Brunekreef B, Chan-Yeung M, Gehring U, Herbarth O, Hoffmann B, Kerkhof M, Klümper C, Koletzko S, Kozyrskyj A, Kull I, Heinrich J, Melén E, Pershagen G, Postma D, Tiesler CMT, Carlsten C. 2013. Childhood Allergic Rhinitis, Traffic-related air pollution, and variability in the GSTP1, TNF, TLR2, and TLR4 genes: results from the TAG study. Journal of Allergy and Clinical Immunology. doi:10.1016/j.jaci.2013.03.007.

http://www.sciencedirect.com/science/article/pii/S0091674913004272.

Gehring U, Cyrys J, Sedlmeir G, Brunekreef B, Bellander T, Fischer P, Bauer CP, Reinhardt D, Wichmann HE, Heinrich J. 2002. Traffic-related air pollution and respiratory health during the first 2 years of life. European Respiratory Journal 19(4):690 -698.

Gehring U, Wijga A, Brauer M, Fischer P, de Jongste JC, Kerkhof M, Oldenwening M, Smit HA, Brunekreef B. 2010. Traffic-related air pollution and the development of asthma and allergies during the first 8 years of life. American Journal of Respiratory and Critical 
Care Medicine 181 (6): 596-603.

Gruzieva O, Bellander T, Eneroth K, Kull I, Melén E, Nordling E, van Hage M, Wickman M, Moskalenko V, Hulchiy O, Pershagen G. 2012. Traffic-related air pollution and development of allergic sensitization in children during the first 8 years of life. Journal of Allergy and Clinical Immunology 129(1):240-246.

Gruzieva O, Gehring U, Aalberse R, Agius R, Beelen R, Behrendt H, Bellander T, Birk M, de Jongste JC, Fuertes E, Heinrich J, Hoek G, Klümper C, Koppelman G, Korek M, Krämer U, Lindley S, Mölter A, Simpson A, Standl M, van Hage M, von Berg A, Wijga A, Brunekreef B, Pershagen G. Meta-analysis of air pollution exposure association with allergic sensitization in European birth cohorts. Journal of Allergy and Clinical Immunology [in press, see Supplementary Material]

Haleko U, Højsgaard S, Yan J. 2006. The R Package Geepack for Generalized estimating equations. Journal of Statistical Software 15(2):1-11.

Heinrich J, Bolte G, Hölscher B, Douwes J, Lehmann I, Fahlbusch B, Bischof W, Weiss M, Borte M, Wichmann HE. 2002. Allergens and endotoxin on mothers' mattresses and total immunoglobulin E in cord blood of neonates. European Respiratory Journal 20(3):617623.

Hoek G, Meliefste K, Cyrys J, Lewné M, Bellander T, Brauer M, Fischer P, Gehring U, Heinrich J, van Vliet P, Brunekreef. 2002. Spatial variability of fine particle concentrations in three European areas. Atmospheric Environment 36(25):4077-4088.

Holloway JW., Francis SS, Fong KM, Yang IA. 2012. Genomics and the respiratory effects of air pollution exposure. Respirology 17(4):590-600.

Krämer U, Sugiri D, Ranft U, Krutmann J, von Berg A, Berdel D, Behrendt H, Kuhlbusch T, Hochadel M, Wichmann HE, Heinrich J. 2009. Eczema, respiratory allergies, and trafficrelated air pollution in birth cohorts from small-town areas. Journal of Dermatological Science 56(2):99-105.

McConnell, R, Berhane K, Yao L, Jerrett M, Lurmann F, Gilliland F, Künzli N, Gauderman J, Avol E, Thomas D, Peters J. 2006. Traffic, susceptibility, and childhood asthma. Environmental Health Perspectives 114:766-772.

MacIntyre E, Gehring U, Mölter A, Fuertes E, Klümper C, Krämer U, Quass U, Hoffmann B, Gascon M, Brunekreef B, Koppelman GH, Beelen R, Hoek G, Birk M, de Jongste J, Smit HA, Cyrys J, Gruzieva O, Korek M, Bergström A, Agius R, de Vocht F, Simpson A, Porta D, Forastiere F, Badaloni C, Cesaroni G, Esplugues A, Fernandez-Somoano A, 
Lerxundi A, Sunyer J, Pershagen G, Heinrich J. Air pollution and respiratory infections during early childhood: an analysis of ten European birth cohorts within the ESCAPE Project. Environmental Health Perspectives [in press, see Supplementary Material] Morgenstern V, Zutavern A, Cyrys J, Brockow I, Koletzko S, Krämer U, Behrendt H, Herbarth O, von Berg A, Bauer CP, Wichmann HE, Heinrich J, for the GINI and LISA Study Groups. 2008. Atopic diseases, allergic sensitization, and exposure to traffic-related air pollution in children. American Journal of Respiratory and Critical Care Medicine 177(12):1331-1337.

Morgenstern V, Zutavern A, Cyrys J, Brockow I, Gehring U, Koletzko S, Bauer CP, Reinhardt D, Wichmann HE, Heinrich J. 2007. Respiratory health and individual estimated exposure to traffic-related air pollutants in a cohort of young children. Occupational and Environmental Medicine 64(1):8 -16.

Nordling E, Berglind N, Melén E, Emenius G, Hallberg J, Nyberg F, Pershagen G, Svartengren M, Wickman M, Bellander T. 2008. Traffic-related air pollution and childhood respiratory symptoms, function and allergies. Epidemiology 19(3):401-408.

Oftedal B, Brunekreef B, Nystad W, Nafstad P. 2007. Residential outdoor air pollution and allergen sensitization in schoolchildren in Oslo, Norway. Clinical \& Experimental Allergy 37(11):1632-1640.

R Core Team. 2012. R: A language and environment for statistical computing. R Foundation for Statistical Computing, Vienna, Austria. ISBN 3-900051-07-0, URL http://www.Rproject.org/.

Reungoat P, Chiron M, Gauvin S, Zmirou-Navier D, Momas I. 2005. Retrospective assessment of exposure to traffic air pollution using the ExTra Index in the VESTA French epidemiological study. Journal of Exposure Science and Environmental Epidemiology 15(6):524-533.

Ryan PH, LeMasters GK, Levin L, Burkle J, Biswas P, Hu S, Grinshpun S, Reponen T. 2008. A land-use regression model for estimating microenvironmental diesel exposure given multiple addresses from birth through childhood. Science of The Total Environment 404(1):139-147.

Sausenthaler S, Standl M, Buyken A, Rzehak P, Koletzko S, Bauer CP, Schaaf B, von Berg A, Berdel D, Borte M, Herbarth O, Lehmann I, Krämer U, Wichmann H-E, Heinrich J for the GINIplus and the LISAplus Study Groups. 2011. Regional and socio-economic differences in food, nutrient and supplement intake in school-age children in Germany: 
Tager I, Demerjian K, Frampton M, Jerrett M, Kelly F, Lobzik L, Künzli N, Leaderer B, Lumley T, Lurmann FW, Richardson S, Samet J, Walsh M. 2010. Traffic-related air pollution: a critical review of the literature on emissions, exposure, and health effects. Boston, Massachusetts: Health Effects Institute.

von Berg A, Koletzko S, Grübl A, Filipiak-Pittroff B, Wichmann HE, Bauer CP, Reinhardt D, Berdel D. 2003. The effect of hydrolyzed cow's milk formula for allergy prevention in the first year of life: the German Infant Nutritional Intervention study, a randomized doubleblind trial. Journal of Allergy and Clinical Immunology 111(3):533-534.

Wang R, Henderson SB, Sbihi H, Allen RW, Brauer M. 2013. Temporal stability of land use regression models for traffic-related air pollution. Atmospheric Environment 64: 312-319. 


\section{Figure 1}

Period prevalence of children with doctor diagnosed asthma or allergic rhinitis at ages three to 10 years

Figure 1: Period prevalence of children with doctor diagnosed asthma (bars with diagonal lines) or allergic rhinitis (filled bars) at ages three to 10 years in the total population (A) and stratified by area: GINI/LISA South (B), GINI/LISA North (C) and LISA East (D) .
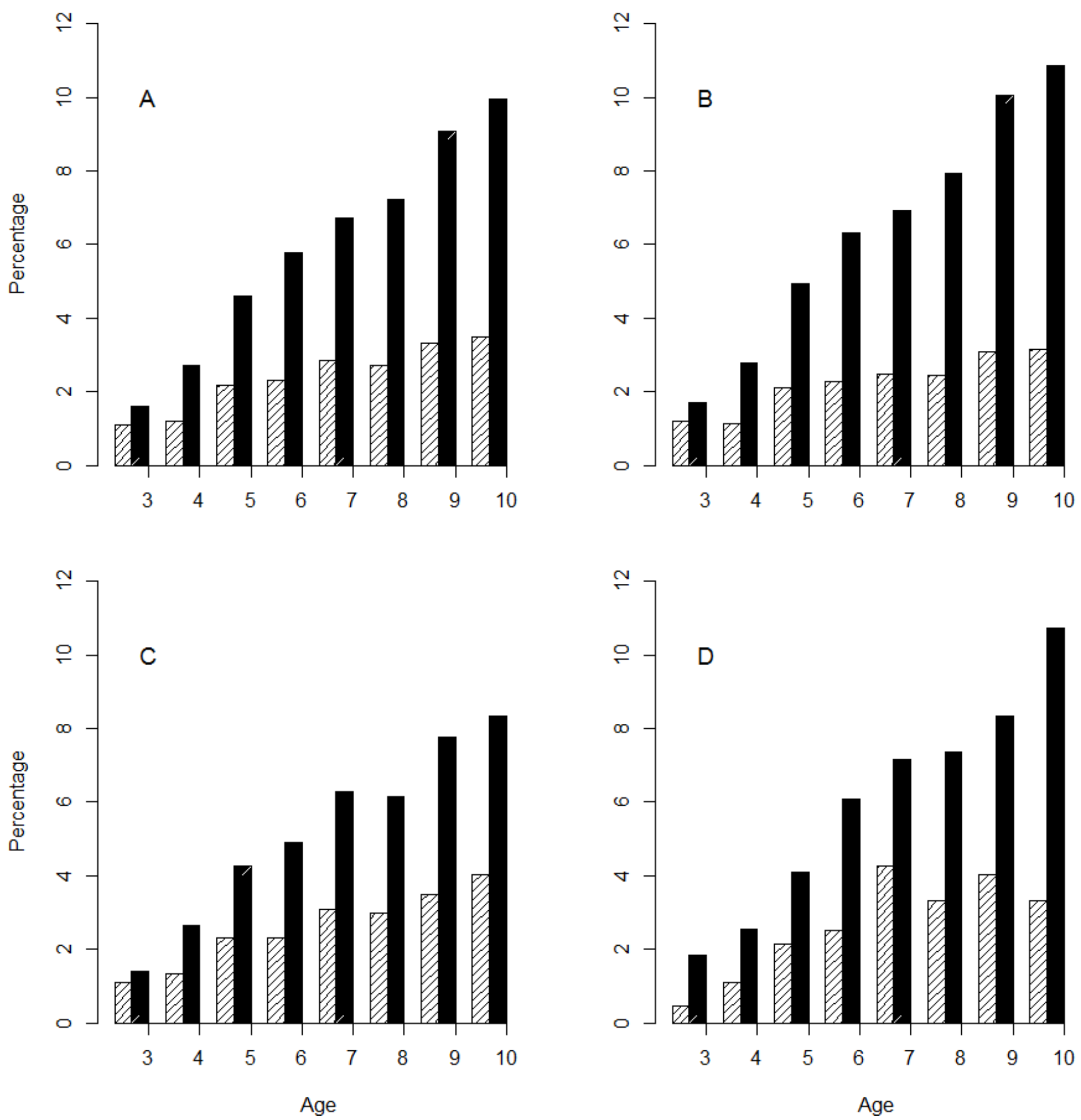


\section{Table 1 (on next page)}

Characteristics of models used to estimate air pollution exposures 
Table 1: Characteristics of models used to estimate air pollution exposures

\begin{tabular}{|c|c|c|c|c|c|c|}
\hline Project & Areas & Air pollution sampling description & Pollutants & $\mathbf{R}^{2}$ & RMSE & Associated publications \\
\hline \multirow[t]{6}{*}{ ESCAPE } & $\begin{array}{l}\text { GINI/LSA } \\
\text { South }=\end{array}$ & $\begin{array}{l}20 \text { sites }(\mathrm{PM}) / 40\left(\mathrm{NO}_{2}\right) \text { in Munich, } \\
\text { Augsburg and small nearby towns }\end{array}$ & $\mathrm{NO}_{2}$ & 0.86 & 5.5 & (Beelen et al. 2013; Cyrys et al. 2012) \\
\hline & $\begin{aligned} \operatorname{south} & \frac{\circlearrowright}{\circlearrowright} \\
& \Xi \\
& 巳\end{aligned}$ & $\begin{array}{l}\text { sampled for three two-week intervals } \\
\text { between } 10.2008 \text { and } 11.2009\end{array}$ & $\mathrm{PM}_{2.5}$ mass & 0.78 & 1.0 & (Eeftens et al. 2012a; Eeftens et al. 2012b) \\
\hline & $\sum^{\bar{\sigma}}$ & & $\mathrm{PM}_{2.5}$ absorbance & 0.91 & 0.2 & \\
\hline & GiNI/ISA & $\begin{array}{l}20 \text { sites }(\mathrm{PM}) / 40\left(\mathrm{NO}_{2}\right) \text { in Dortmund, } \\
\text { Duisburg, Essen and smaller towns }\end{array}$ & $\mathrm{NO}_{2}$ & 0.89 & 4.3 & (Beelen et al. 2013; Cyrys et al. 2012) \\
\hline & 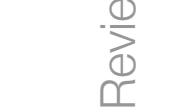 & $\begin{array}{l}\text { sampled for three two-week intervals } \\
\text { between } 10.2008 \text { and } 10.2009\end{array}$ & $\mathrm{PM}_{2.5}$ mass & 0.88 & 0.9 & (Eeftens et al. 2012a; Eeftens et al. 2012b) \\
\hline & & & $\mathrm{PM}_{2.5}$ absorbance & 0.97 & 0.1 & \\
\hline \multirow[t]{2}{*}{ TRAPCA } & LISA ist & $\begin{array}{l}30 \text { sites sampled for four two-week } \\
\text { intervals between } 04.2004 \text { and } 03.2005\end{array}$ & $\mathrm{NO}_{2}$ & 0.81 & 2.7 & - \\
\hline & 口L & & $\mathrm{PM}_{2.5}$ mass & 0.55 & 0.1 & - \\
\hline APMoSPHERE & $\begin{array}{l}\text { GINI/LISA } \\
\text { South and } \\
\text { North, and } \\
\text { LISA East }\end{array}$ & $\begin{array}{l}\text { Air pollution data for } 2001 \text { obtained } \\
\text { from Airbase (air quality database from } \\
\text { routine air pollution monitoring } \\
\text { covering } 15 \text { European member states; } \\
\text { resolution } 1 \times 1 \mathrm{~km} \text { ) }\end{array}$ & Ozone & 0.70 & 7.7 & (Beelen et al. 2009) \\
\hline
\end{tabular}

$\mathrm{R}^{2}=$ Model explained variance; $\mathrm{RMSE}=$ Root-mean standard errors 


\section{Table 2 (on next page)}

Characteristics of study participants 
Table 2: Characteristics of study participants

\begin{tabular}{|c|c|c|c|c|c|c|c|c|}
\hline \multirow{2}{*}{ General characteristics } & \multicolumn{2}{|c|}{$\begin{array}{c}\text { Total } \\
\mathbf{N}=6604\end{array}$} & \multicolumn{2}{|c|}{$\begin{array}{c}\text { GINI/LISA South } \\
\qquad \mathbf{N}=3362\end{array}$} & \multicolumn{2}{|c|}{$\begin{array}{c}\text { GINI/LISA North } \\
\qquad \mathbf{N}=\mathbf{2 5 5 1}\end{array}$} & \multicolumn{2}{|c|}{$\begin{array}{c}\text { LISA East } \\
\quad \mathrm{N}=691\end{array}$} \\
\hline & $\mathbf{n} / \mathbf{N}$ & $\%$ & $\mathbf{n} / \mathbf{N}$ & $\%$ & $\mathbf{n} / \mathbf{N}$ & $\%$ & $\mathbf{n} / \mathbf{N}$ & $\%$ \\
\hline Males $\quad \frac{\bar{T}}{0}$ & $3386 / 6604$ & 51.3 & $1747 / 3362$ & 52.0 & $1304 / 2551$ & 51.1 & $335 / 691$ & 48.5 \\
\hline Presence of older siblings & $3021 / 6588$ & 45.9 & $1398 / 3357$ & 41.6 & $1378 / 2542$ & 54.2 & $245 / 689$ & 35.6 \\
\hline \multicolumn{9}{|l|}{ Parental education $\quad \frac{\bar{\sigma}}{>}$} \\
\hline Less than or equal to 10 years & $2405 / 6573$ & 36.6 & $759 / 3350$ & 22.7 & $1342 / 2542$ & 52.8 & $304 / 681$ & 44.6 \\
\hline More than $10 \stackrel{\subsetneq}{\text { 尊ars }}$ & $4168 / 6573$ & 63.4 & $2591 / 3350$ & 77.3 & $1200 / 2542$ & 47.2 & $377 / 681$ & 55.4 \\
\hline \multicolumn{9}{|l|}{ Smoking $\quad=\frac{\partial}{>}$} \\
\hline During pregnascy & $943 / 6248$ & 14.7 & $430 / 3268$ & 13.2 & $403 / 2494$ & 16.2 & $110 / 666$ & 16.5 \\
\hline Ever in home -4 years) & $2212 / 5663$ & 39.1 & $887 / 2987$ & 29.7 & $1096 / 2099$ & 52.2 & $229 / 577$ & 39.7 \\
\hline Parental history of atop & $3750 / 6534$ & 57.4 & $2232 / 3340$ & 66.8 & $1221 / 2535$ & 48.2 & $297 / 659$ & 45.1 \\
\hline Owned furry pet durin $\$$ prly life & $1126 / 6343$ & 17.8 & $504 / 3237$ & 15.6 & $444 / 2430$ & 18.3 & $178 / 676$ & 26.3 \\
\hline Gas used in home du In early life & $469 / 6447$ & 7.3 & $257 / 3301$ & 7.8 & $106 / 2474$ & 4.3 & $106 / 672$ & 15.8 \\
\hline Mold/dampness in home during early life & $1330 / 5312$ & 25.0 & $797 / 2889$ & 27.6 & $379 / 1751$ & 21.6 & $154 / 672$ & 22.9 \\
\hline Moved between one and 10 years & $3197 / 5407$ & 59.1 & $1739 / 2935$ & 59.3 & $1061 / 1930$ & 55.0 & $397 / 542$ & 73.2 \\
\hline \multicolumn{9}{|l|}{ Cohort } \\
\hline GINIplus & $4386 / 6604$ & 66.4 & $2107 / 3362$ & 62.7 & $2279 / 2551$ & 89.3 & $0 / 691$ & 0.0 \\
\hline LISAplus & $2218 / 6604$ & 33.6 & $1255 / 3362$ & 37.3 & $272 / 2551$ & 10.7 & $691 / 691$ & 100.0 \\
\hline Intervention participation ${ }^{1}$ & $1935 / 6604$ & 29.3 & $1031 / 3362$ & 30.7 & $904 / 2551$ & 35.4 & $0 / 691$ & 0.0 \\
\hline \multicolumn{9}{|l|}{ Health outcomes (at age 10 years) } \\
\hline Doctor diagnosed asthma & $164 / 4696$ & 3.5 & $82 / 2589$ & 3.2 & $68 / 1684$ & 4.0 & $14 / 423$ & 3.3 \\
\hline Doctor diagnosed allergic rhinitis & $460 / 4623$ & 10.0 & $275 / 2528$ & 10.9 & $140 / 1676$ & 8.4 & $45 / 419$ & 10.7 \\
\hline Eyes and nose symptoms & $628 / 4736$ & 13.3 & $389 / 2585$ & 15.0 & $173 / 1722$ & 10.0 & $66 / 429$ & 15.4 \\
\hline Sensitized to aeroallergens & $1100 / 2735$ & 40.2 & $678 / 1581$ & 42.9 & $303 / 867$ & 34.9 & $119 / 287$ & 41.5 \\
\hline Sensitized to indoor aeroallergens & $748 / 2732$ & 27.4 & $449 / 1579$ & 28.4 & $214 / 866$ & 24.7 & $85 / 287$ & 29.6 \\
\hline
\end{tabular}


${ }^{1}$ Intervention only part of the GINIplus cohort

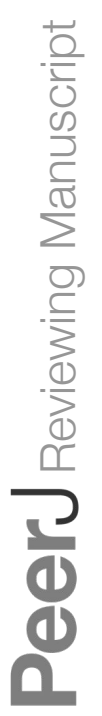




\section{Table 3 (on next page)}

Distribution of estimated annual average concentrations of pollutants

Distribution of estimated annual average concentrations of $\mathrm{NO}_{2}, \mathrm{PM}_{2.5}$ mass, $\mathrm{PM}_{2.5}$ absorbance and ozone at the birth address in the total dataset and per area. 
1 Table 3: Distribution of estimated annual average concentrations of $\mathrm{NO}_{2}, \mathrm{PM}_{2.5}$ mass, $\mathrm{PM}_{2.5}$

2 absorbance and ozone at the birth addresses in the total dataset and per area

\begin{tabular}{|cllllllll|}
\hline Air pollutant & $\mathbf{N}$ & Min & $\mathbf{0 . 2 5}$ & Median & Mean & $\mathbf{0 . 7 5}$ & Max & IQR \\
\hline $\mathrm{NO}_{2}\left(\mu \mathrm{g} / \mathrm{m}^{3}\right)$ & & & & & & & & \\
Total population & 6485 & 11.5 & 18.9 & 22.2 & 22.4 & 25.0 & 62.8 & 6.1 \\
GINI/LISA South & 3306 & 11.5 & 17.3 & 20.7 & 21.7 & 25.4 & 61.1 & 8.1 \\
GINI/LISA North & 2491 & 19.7 & 21.8 & 23.2 & 23.8 & 25.1 & 62.8 & 3.3 \\
LISA East & 688 & 18.5 & 18.7 & 18.8 & 20.8 & 22.4 & 34.8 & 3.7 \\
$\mathrm{PM}_{2.5}$ mass $\left(\mu \mathrm{g} / \mathrm{m}^{3}\right)$ & & & & & & & & \\
Total population & 6485 & 0.4 & 13.3 & 15.4 & 15.3 & 17.3 & 21.5 & 4.0 \\
GINI/LISA South & 3306 & 10.6 & 12.8 & 13.3 & 13.4 & 14.0 & 18.3 & 1.2 \\
GINI/LISA North & 2491 & 15.8 & 16.9 & 17.3 & 17.4 & 17.8 & 21.5 & 0.9 \\
LISA East & 688 & 0.4 & 17.2 & 17.8 & 17.5 & 18.34 & 20.1 & 1.2 \\
$\mathrm{PM}_{2.5}$ absorbance $\left(10^{-5} / \mathrm{m}\right)$ & & & & & & & & \\
Total population & 5797 & 1.0 & 1.2 & 1.5 & 1.5 & 1.7 & 3.6 & 0.5 \\
GINI/LISA South & 3306 & 1.3 & 1.6 & 1.7 & 1.7 & 1.8 & 3.6 & 0.2 \\
GINI/LISA North & 2491 & 1.0 & 1.1 & 1.2 & 1.2 & 1.3 & 3.1 & 0.2 \\
LISA East & - & - & - & - & - & - & - & - \\
Ozone ( $\mu$ g/m $\left.{ }^{3}\right)$ & & & & & & & & \\
Total population & 6604 & 32.3 & 39.6 & 42.9 & 42.5 & 44.8 & 59.4 & 5.2 \\
GINI/LISA South & 3362 & 34.1 & 44.1 & 44.7 & 45.8 & 45.5 & 59.4 & 1.4 \\
GINI/LISA North & 2551 & 32.3 & 34.4 & 38.0 & 38.2 & 41.4 & 54.3 & 7.0 \\
LISA East & 691 & 38.0 & 41.0 & 41.8 & 41.9 & 42.5 & 52.9 & 1.5 \\
\hline
\end{tabular}




\section{Table 4 (on next page)}

Total and area-specific associations between air pollutants estimated to the birth address and health outcomes during the first 10 years of life 
Table 4: Total and area-specific associations between air pollutants estimated to the birth address and health outcomes during the first 10 years of life*

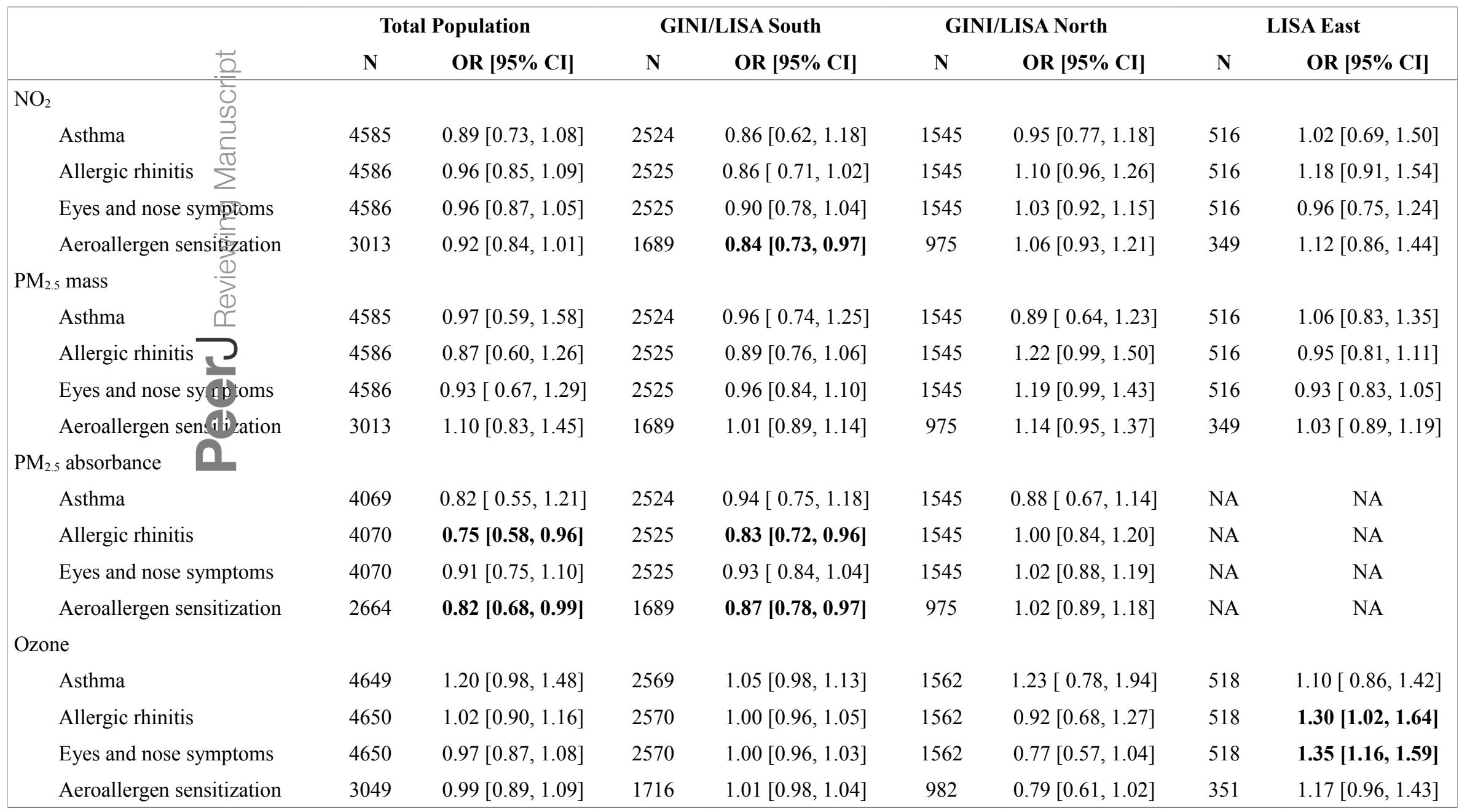

Bold $=$ statistically significant result (p-value $<0.05) . *$ Odds ratios are calculated per interquartile increase of each air pollutant. Models are adjusted for sex, age, parental history of atopy, parental education, older siblings, maternal smoking during pregnancy, smoke exposure in the home, contact with furry pets, use of gas stove for cooking, home dampness or indoor mold, intervention participation, cohort and area (total models only). 